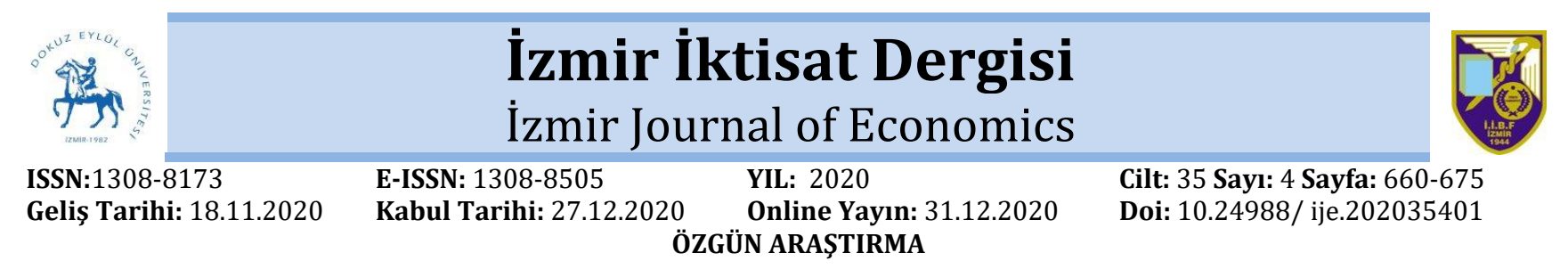

\title{
Covid-19 Pandemisinde Normalleşme Sürecinin Toplumsal ve Ekonomik Açıdan Değerlendirilmesi
}

\author{
Nükhet HOTAR ${ }^{1}$, Rabia Ece OMAY ${ }^{2}$, Serdar BAYRAK ${ }^{3}$, Ziya KURUÜZÜM ${ }^{4}$, Belgin ÜNAL ${ }^{5}$
}

\begin{abstract}
Özet
İlk olarak 2019 yılında Çin'de saptanan Covid-19 hastalığı kısa sürede hızla yayılmış ve 11 Mart 2020 tarihinde Dünya Sağlık Örgütü tarafindan küresel pandemi ilan edilmiștir. Türkiye bu süreçte pandemi ile ilgili tedbirlerini oldukça erken bir dönemde almaya başlamış ve Dünya Sağlık Örgütü' nün pandemi ilanından önce, 10 Ocak 2020 tarihinde Covid-19 hastalı̆̆ı ile mücadele etmek amacıyla Sağlık Bakanlığı bünyesinde bir operasyon merkezi kurulmuş ve aynı tarihte Türkiye'nin farklı üniversitelerinde farklı alanlarda çalışan başarılı bilim adamlarından oluşan bir Bilim Kurulu olușturulmuștur. Ardından tüm dünyada olduğu gibi Türkiye'de de hayatın her alanında sosyal izolasyon dönemi bașlamıștır. 6 Mayıs 2020 tarihinde Sağlık Bakanı Fahrettin Koca'nın pandemi ile ilgili birinci dönemin tamamlandığını duyurmasının ardından, 1 Haziran 2020 tarihinde ülkemizde önceden belirlenen takvim çerçevesinde normalleşme süreci başlamıştır. Bu çalışmada Dokuz Eylül Üniversitesi pandemi polikliniğine 18.03.2020-15.11.2020 tarihleri arasında başvuran hastaların tanı kriterlerine bağlı olarak değerlendirilme süreçleri ve buna bağlı sosyo-demografik özellikleri normalleşme süreci açısından irdelenmiştir. Bununla birlikte Covid-19 tedbirleri kapsamında yaşanan toplu izolasyonun ardından gelen normalleşme sürecinin toplumsal ve ekonomik açıdan karşılaştırmalı değerlendirilmesine yer verilmiştir.
\end{abstract}

Anahtar kelimeler:Covid-19, Normalleşme Süreci, Sosyo-ekonomik etki

Jel Kodu: I18, A13

\section{Social And Economic Evaluation of the Normalization Process In Covid-19 Pandemic}

\begin{abstract}
Covid-19 disease, first detected in China in 2019, spread rapidly in a short time and was declared a global pandemic by the World Health Organization on March 11, 2020. Turkey has begun to take quite an early stage of the pandemic-related measures in this process. Before the World Health Organization declared a pandemic, an operations center has been established within the Ministry of Health to combat Covid-19 on 10 January 2020. And at the same time, working in different areas at different universities in Turkey has created a Science Committee composed of successful scientists. Then, in Turkey as well as all over the world in all areas of life, social isolation period has begun. After the Minister of Health Fahrettin Koca announced on May 6, 2020 that the first period regarding the pandemic was completed, the normalization process started in our country on June 1, 2020 within the pre-determined schedule. In this study, the evaluation processes of the patients who applied to the Dokuz Eylül University pandemic outpatient clinic between 18.03.2020-15.11.2020, depending on the diagnostic criteria, and the related socio-demographic characteristics were examined in terms of the normalization process. In addition, social and economic comparative evaluation of the normalization process that followed the collective isolation under Covid-19 measures was included.
\end{abstract}

Keywords: Covid-19, Normalization process, Socio-economic impact

Jel Codes: I18, A13

ATIF ÖNERISİ (APA): Hotar, N. Omay, R. E., Bayrak, S., Kuruüzüm, Z., Ünal, B. (2020). Covid-19 Pandemisinde Normalleşme Sürecinin Toplumsal ve Ekonomik Açıdan Değerlendirilmesi. İzmir İktisat Dergisi, 35(4), 660-592. Doi: 10.24988/ije.202035401

1 Prof. Dr., Dokuz Eylül Üniversitesi, Alsancak / IZMIR, EMAIL: nukhethotar@deu.edu.tr ORCID: 0000-0002-2195-0852 2 Doç. Dr., Dokuz Eylül Üniversitesi, İktisadi ve İdari Bilimler Fakültesi, Buca / İZMİR, EMAIL: rabiaece.omay@deu.edu.tr ORCID: 0000-0002-3819-4563

${ }^{3}$ Doç. Dr., Dokuz Eylül Üniversitesi, Tıp Fakültesi, Narlıdere / İZMİR, EMAIL: serdar.bayrak@deu.edu.tr ORCID: 0000-0003-1458-9023

4 Prof. Dr., Dokuz Eylül Üniversitesi, Tıp Fakültesi, Narlıdere / İZMİR, EMAIL: ziya.kuruuzum@deu.edu.tr ORCID: 0000-0002-1095-8226

5 Prof. Dr., Dokuz Eylül Üniversitesi, Tıp Fakültesi, Narlıdere / İZMİR, EMAIL: belgin.unal@deu.edu.tr

ORCID: 0000-0002-4354-8266 


\section{Gíriș}

İlk olarak 2019 yılında Çin'de saptanan Coronavirüs kaynaklı Covid-19 hastalı̆̆ı ile ilgili bilginin Dünya Sağlık Örgütü'ne (DSÖ) hemen iletilmesi ve gerekli önlemlerin alınmasına rağmen, hastalık süreç içerisinde hızla yayılmış ve 11.03.2020 tarihinde DSÖ tarafından küresel pandemi ilan edilmiştir (www.who.int, 2020a).

Türkiye bu süreçte pandemi ile ilgili tedbirlerini oldukça erken bir dönemde almaya başlamış ve DSÖ'nün pandemi ilanından önce, 10.01.2020 tarihinde Covid-19 hastalı̆̆ ile mücadele etmek amacıyla Sağlık Bakanlığı bünyesinde bir operasyon merkezi kurulmuş ve aynı tarihte Türkiye'nin farklı üniversitelerinde, enfeksiyon hastalıkları ve klinik mikrobiyoloji, çocuk enfeksiyon hastalıkları, halk sağlığı, göğüs hastalıkları, yoğun bakım ve iç hastalıları, dahili tıp, acil tıp, epidemiyoloji gibi farklı alanlarda çalışan bilim adamlarından oluşan bir Bilim Kurulu oluşturulmuştur (Yener, 2020). Bilim Kurulunun oluşturulmasının ardından tedbirler alınmaya devam etmiștir. 24.01.2020'de havaalanlarına termal kameralar kurulmuş, 03.02.2020'de Çin'den gelen tüm uçuşlar durdurulmuş, 29.02.2020 tarihinde İtalya, Güney Kore ve Irak ile tüm uçuşlar karşılıklı durdurulmuş, ardından Irak sınırı kapatılmıştır (www.tuba.gov.tr, 2020). 8 Mart 2020 tarihinde bazı illerde halka açık yerlerde ve toplu taşıma araçlarında dezenfeksiyon işlemleri başlatılmıștır.

Erken dönemde alınan tüm tedbirler sayesinde, bulunduğumuz coğrafi konuma göre geç bir tarihte, 11.03.2020'de Sağlık Bakanı Fahrettin Koca tarafından ülkemizde tespit edilen ilk vaka açıklaması yapılmıştır (www.bbc.com, 2020). 17.03.2020'de karantinaya alınan bir hastanın öldügü açıklanmış ve bu Türkiye'de kayıtlara geçen ilk ölümlü vaka olmuştur (https://tr.euronews.com, 2020). Sağlık Bakanlığı 20.03.2020 tarih ve 14500235403.99 sayılı bir genelge yayınlanmış ve tüm hastanelerin pandemi hastanesi olduğunu duyurmuştur (hasta.saglik.gov.tr, 2020). Ardından 25.03.2020 tarihinde Milli Eğitim Bakanı Ziya Selçuk okulların 30 Nisana kadar tatil edildiğini duyurmuştur (www.meb.gov.tr, 2020a, 2020b). 01.04.2020'de Sağlık Bakanı Fahrettin Koca tarafından yapılan açıklamada, Türkiye'de 81 ilin tamamında tespit edilen Covid-19 vakalarının olduğu, en yüksek vaka sayısının İstanbul'da gözlendiği ve İstanbul'u İzmir ve Ankara illerinin takip ettiği belirtilmiştir.

Dünya Sağlık Örgütü'nün pandemi ilanı ile birlikte Sağlık Bakanlığı Bilim Kurulu'nun oluşturduğu algoritmalara uygun olarak, Dokuz Eylül Üniversite (DEÜ) Sağlık Yerleşkesi'nde de yönetsel ve tıbbi açıdan tüm değerlendirmeler gerçekleştirilmiş ve süreç bu prensiplerle sürdürülmeye devam edilmiştir.

Bu çalışmada Dokuz Eylül Üniversitesi pandemi polikliniğine 18.03.2020-15.11.2020 tarihleri arasında başvuran hastaların tanı kriterlerine bağlı olarak değerlendirilme süreçleri ve buna bağlı sosyo-demografik özellikleri irdelenmiștir. Bununla birlikte Covid-19 tedbirleri kapsaminda yaşanan toplu izolasyonun ardından gelen "normalleşme süreci"nin toplumsal ve ekonomik açıdan değerlendirilmesine yer verilmiştir.

\section{METOD}

$\mathrm{Bu}$ kesitsel araştırmada araştırma grubunu 18.03.2020-15.11.2020 periyodunda DEÜ Araștırma Uygulama Hastanesine başvurup olası Covid-19 (U07.3) tanı kodu ile izlenen hastalar oluşturmaktadır. Çalışmada hastaların yaş, cinsiyet, meslek, sağlık çalışanı olma durumu, Dokuz Eylül Üniversitesi Tıp Fakültesi (DEÜTF) çalıșanı olma durumu, vakaların huzur evi ile ilişkili olma durumu, gibi bilgiler, yani araştırma grubunu oluşturan hastalara ait bilgiler hastane bilgi sistemi (PROBEL) kayıtlarından elde edilmiştir. U07.3 tanı kodu alan hastaların nazofarengeal sürüntü örnek sonucu Sağlık Bakanlığının Covid-19 hastalarının sürveyansı kapsamında 
oluşturduğu Halk Sağlığı Yönetim Sisteminden alınmıştır. Daha önce Hotar, N. v.d. (2020) 18.03.2020-24.04.2020 periyodu için izolasyon dönemi ve yeni normale geçişin nasıl olması gerektiğini değerlendirmiştir. Bu çalışmada ise 442 vakayı içeren 18.03.2020-24.04.2020 periyodu 1. Dönem ve 3376 vakayı içeren 18.03.2020-15.11.2020 periyodu ise 2. Dönem olarak belirlenmiş ve her iki dönem, söz konusu değişkenlerde gözlenen artış ve azalışlar açısından karşılaştırılmış, değerlendirilmiştir. Vakaların sağlık çalışanı olma durumu, vakaların huzurevi ile ilgili olma, huzurevi sakini ve çalışanı olma durumları ise verilere erişim açısından 13.09.2020 tarihine kadar elde edilmiştir. Dolayısıyla bu dört değişken için (Tablo 5, Tablo7-8) 2. Dönem 18.03.202018.03.2020 zaman aralığındaki 1644 vakayı içermektedir.

\section{SAĞLIK VERILLERININN NORMALLEŞME SÜRECİNDE DEĞERLENDİRILMESİ}

PROBEL kayıtlarına göre, 18.03.202015.11.2020 tarihleri arasında sistemde Sağlık Bakanlığı'nın U07.03 kodu ile bildirim istediği Covid-19 olası tanılı hastalarda yapılan PCR taramaları sonucunda kesin vaka olarak 3376 hasta tanımlanmıştır.

Kesin vaka olarak tanımlanan hastalara ilişkin,

- Vakaların cinsiyete göre dağılımı (Tablo1)

- Vakaların yaş durumu (Tablo2)

- Vakaların yaş gruplarına göre dağılımı (Tablo3)

- Vakaların onlu yaş gruplarına göre dağılımı (Tablo4)

- Vakaların sağlık çalışanı olma durumu (Tablo5)

- Vakaların DEÜTF çalışanı olma durumu (Tablo6)

- Vakalarin huzurevi ile ilgili olma durumu (Tablo7)

- Vakalarin huzurevi sakini olma durumu (Tablo8)

- Vakaların huzurevi çalışanı olma durumu (Tablo9) incelenmiș ve Tablo1-9'da hem 18.03.202024.04.2020 periyoduna (1. Dönem) (Hotar v.d., 2020) hem de 18.03.2020-15.11.2020 periyoduna (2. Dönem) yer verilmiştir. Tablo1 incelendiğinde 2 . dönemde söz konusu hastaların \%50.9'unun kadın, \%49.1'inin erkek olduğu gözlenmiştir. $\mathrm{Bu}$ oranların her iki dönemde de birbirine çok yakın olduğu görülmektedir. Dolayısıyla 2. dönemde de cinsiyetin Covid-19 virüsüne yakalanma riski üzerinde doğrudan belirleyici bir etkisi olmadığı söylenebilir. Tablo2'ye göre 1 . dönemde vakaların yaş ortalaması 22.1 standart sapma ile 51.6 iken 2. dönemde bu değer 19.6 standart sapma ile 41.2'ye düşmüştür. En küçük vaka yaşının 0, en büyük vaka yaşının ise 101 olduğu görülmektedir.

Tablo3' de görülmektedir ki, 18.03.202015.11.2020 periyodunda, 18 yaş altı nüfusta Covid-19 vakası görülmesi oranı \%10.8'dir. Bu oran 1. döneme göre yüksek bir orandır. 1 . dönemde, ilk Covid-19 vakasının görülmesinin hemen ardından 12.03.2020 tarihi itibarıyla Milli Eğitim Bakanlığı ve Yükseköğretim Kurulu tarafından yüz yüze eğitime ara verilmiş ve uzaktan eğitime geçilmiştir (www.meb.gov.tr, 2020a, 2020b; covid19.yok.gov.tr, 2020). 03.04.2020 tarihinde de genç nüfusu korumaya yönelik alınan ikinci bir kararla 20 yaş altındaki nüfusa sokağa çıkma kısıtlaması getirilmişti (www.icisleri.gov.tr, 2020a). Hem uzaktan eğitime geçilmesinin hem de 20 yaş altı nüfusun sokağa çıkma kısıtlamasının, 18 yaş altında vaka oranının düşük kalmasında büyük bir etken olduğu söylenebilir (Hotar vd., 2020). Elbette bu nokta da belirleyici olan diğer unsur, 06.05.2020 tarihinde Sağlık Bakanı Fahrettin Koca'nın pandemi ile ilgili birinci dönemin tamamlandığını duyurmasının ardından (Yener D., Karaaslan D.S., 2020), 01.06.2020 tarihinde ülkemizde önceden belirlenen takvim çerçevesinde normalleşme sürecinin başlamasıdır. Normalleşme süreciyle birlikte kısıtlamaların kaldırılması ile özellikle 18'den küçük yaş grubundaki oran yaklaşık \%3'den \%11'e yükselmiştir. 
Tablo 1: Vakaların cinsiyete göre dağılımı.

\begin{tabular}{|l|c|c|c|c|}
\hline & \multicolumn{2}{|c|}{ 1. Dönem* } & \multicolumn{2}{c|}{ 2. Dönem** } \\
\hline Cinsiyet & N & $\%$ & N & \% \\
\hline Kadın & 223 & 50.5 & $\mathbf{1 7 5 7}$ & $\mathbf{5 0 . 9}$ \\
\hline Erkek & 219 & 49.5 & $\mathbf{1 6 5 9}$ & $\mathbf{4 9 . 1}$ \\
\hline Toplam & 442 & 100 & $\mathbf{3 3 7 6}$ & $\mathbf{1 0 0}$ \\
\hline
\end{tabular}

* 18.03.2020-24.04.2020 periyodu

** 18.03.2020-15.11.2020 periyodu

Tablo 2: Vakaların yaş durumu.

\begin{tabular}{|c|c|c|c|c|c|c|}
\cline { 2 - 7 } \multicolumn{1}{c|}{} & \multicolumn{3}{c|}{ 1. Dönem* } & \multicolumn{3}{c|}{ 2. Dönem** } \\
\hline Yaş & $\begin{array}{c}\text { Ort. } \\
\text { (St. S.) }\end{array}$ & EnK. & EnB. & $\begin{array}{c}\text { Ort. } \\
\text { (St.S.) }\end{array}$ & EnK. & EnB. \\
\hline $\begin{array}{c}51.6 \\
(22.1)\end{array}$ & 2 & 96 & $\begin{array}{c}\mathbf{4 1 . 2} \\
\mathbf{( 1 9 . 6 )}\end{array}$ & $\mathbf{0}$ & $\mathbf{1 0 1}$ \\
\hline
\end{tabular}

* 18.03.2020-24.04.2020 periyodu

** 18.03.2020-15.11.2020 periyodu

Tablo 3: Vakaların yaş gruplarına göre dağılımı.

\begin{tabular}{|c|c|c|c|c|}
\hline & \multicolumn{2}{|c|}{ 1. Dönem* } & \multicolumn{2}{|c|}{ 2. Dönem** } \\
\hline Yaș Grubu & $\mathrm{N}$ & $\%$ & $\mathbf{N}$ & $\%$ \\
\hline 18'den küçük & 12 & 2.7 & 365 & 10.8 \\
\hline $18-64$ & 301 & 68.1 & 2577 & 76.3 \\
\hline 65 ve üzeri & 129 & 29.2 & 434 & 12.9 \\
\hline Toplam & 442 & 100 & 3376 & 100 \\
\hline
\end{tabular}

Buna karşın 65 yaş ve üzeri grupta birinci dönem ait oran \%29.2 iken, ikinci dönemde \%12.9'a düşmüştür. Bu oranın düşmesinde 65 yaş üstü grubun kontrollü normalleşme sürecine iyi uyum sağlaması, aktif çalışma hayatı içerisinde olmaması ve hastalıktan çok etkilenen grup olması nedeniyle alınan tedbirler konusunda bu grubun hassasiyetlerinin yüksek olması durumları değerlendirilebilir. Diğer bir faktör ise Tablo 8'de görüldüğ̈ gibi, ikinci dönemde vakaların huzur evi sakini olma oranı $(5,6)$ birinci döneme göre (20.6) büyük oranda azalmıştır.

18-64 yaş arası grup diğer bir ifadeyle aktif çalışma hayatı içinde olan grup ise birinci dönemde olduğu gibi en yüksek vaka oranına (\%68.1) sahiptir ve bu oran ikinci dönemde daha da artmıştır (\%76.3).

TÜİK Bölgesel istatistiklerine göre 2019 yılında İzmir ili 0-19 yaş arası nüfusun oranı toplam nüfusa göre \%24.8'dir, 19-64 yaş arası \%63.9 ve 65 yaş ve üzeri \%11.3'dür (biruni.tuik.gov.tr, 2020). Bu oranlar dikkate alındığında, 0-19 yaş aralığında vaka oranlarının 65 yaş ve üstü yaş grubuna göre yüksek çıkması beklenmektedir. Fakat 65 yaş ve üstü grupta vaka oranının düşmesine rağmen hala 0-19 yaş grubuna göre yüksektir. $\mathrm{Bu}$ oranının yüksek olmasının birincil sebebi, hastalığın yaşlı nüfusu daha çok etkilemesidir. Belirlenen zaman periyodunda en düşük vefat yaşı birinci dönemde 45 iken ikinci dönemde 35 'e kadar düşmüştür.

Tablo 4: Vakaların onlu yaş gruplarına göre dağılımı.

\begin{tabular}{|l|c|c|c|c|}
\hline & \multicolumn{2}{|c|}{ 1. Dönem* } & \multicolumn{2}{c|}{ 2. Dönem** } \\
\hline Yaș Grubu & N & $\%$ & N & \% \\
\hline $0-9$ & 2 & 0.5 & $\mathbf{1 7 3}$ & $\mathbf{5 . 1}$ \\
\hline $10-19$ & 15 & 3.4 & $\mathbf{2 2 1}$ & $\mathbf{6 . 5}$ \\
\hline $20-29$ & 54 & 12.2 & $\mathbf{5 9 7}$ & $\mathbf{1 7 . 7}$ \\
\hline $30-39$ & 86 & 19.5 & $\mathbf{7 0 4}$ & $\mathbf{2 0 . 9}$ \\
\hline $40-49$ & 82 & 18.6 & $\mathbf{6 2 4}$ & $\mathbf{1 8 . 5}$ \\
\hline $50-59$ & 56 & 12.7 & $\mathbf{4 5 6}$ & $\mathbf{1 3 . 5}$ \\
\hline $60-69$ & 30 & 6.8 & $\mathbf{2 9 0}$ & $\mathbf{8 . 6}$ \\
\hline $70-79$ & 44 & 10.0 & $\mathbf{1 7 5}$ & $\mathbf{5 . 2}$ \\
\hline 80 ve üzeri & 73 & 16.5 & $\mathbf{1 3 6}$ & $\mathbf{4 . 0}$ \\
\hline Toplam & 442 & 100 & $\mathbf{3 3 7 6}$ & $\mathbf{1 0 0}$ \\
\hline
\end{tabular}

* 18.03.2020-24.04.2020 periyodu

** 18.03.2020-15.11.2020 periyodu

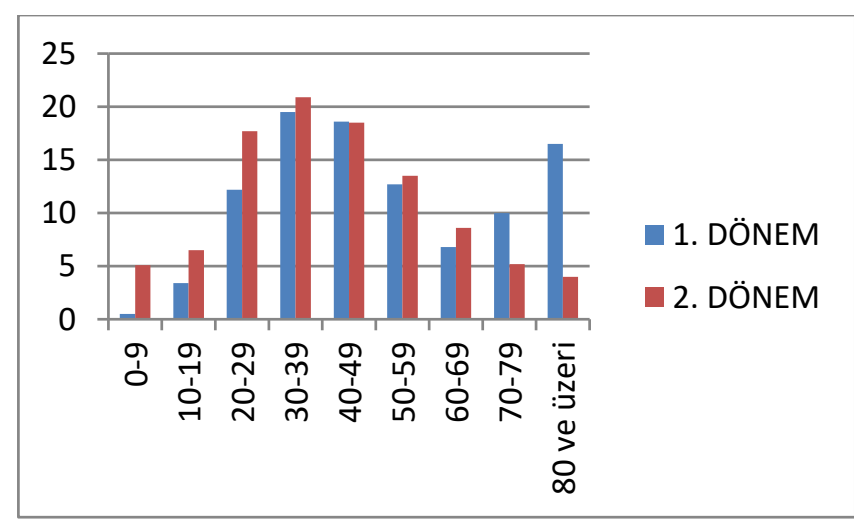

Şekil 1: Vaka oranlarının onlu yaş gruplarına göre dağılımı.

Hastaların yaş ortalaması (19.6 standart sapma ile) 41 olarak tespit edilen hasta grubunun yapılan detaylı yaş analizinde (Tablo4) neredeyse her yaş grubunda hasta görülmekle beraber vakaların \%71' e yakınının 20-60 yaş aralığında olduğu saptanmıştır. Birinci 
dönemde bu aralıktaki detay analiz kümelenme 30-50 yaş aralığındaydı. İkinci dönemde ise söz konusu aralıktaki detay analizde ise kümelenmenin en çok 30-40 yaş aralığındaki toplumun üretken ve aktif kesiminde olduğu tespit edilmiştir. Ayrica bu hasta grubunun yaplan anamnez değerlendirmesinde neredeyse tamamının aktif ve pandemi sırasında çalışıyor olduğu tespit edilmiştir. Aktif çalışan bu hasta grubunun \%22.9'luk kısmını sağlık çalışanları oluşturmaktaydı. Normalleşme takvimi ile beraber iş yerlerinin açılması ve sosyal ortamlardaki iletişimin artmasıyla birlikte $30-50$ yaş grubunda başlangıçta daha çok sağlık çalışanlarında görülen kümelenme neredeyse tüm meslek gruplarını etkilemeye başlamış, hatta yurtdışı birçok makalede de görüldügü gibi hastaneler neredeyse sosyal ortamlardan çok daha güvenli hale gelmiştir. Tablo5' de görüldüğ̈ gibi, aktif çalışan bu hasta grubun \%9'luk kısmı sağlık çalışanlarıdır ve bu oran 18.03.202013.09.2020 periyodu için incelenmiştir. Tablo6 incelendiğinde vakaların \%7.1'inin ise DEÜTF çalışanı olduğu görülmektedir. Birinci dönem ile ikinci dönem arasındaki sağlık çalışanları ve DEÜTF çalışanları oranlarındaki azalma Şekil 2 ve Şekil 3' de de açık bir şekilde gözlenmektedir.

Pandemi sürecinin başından itibaren almış olduğu birçok karar ile Dokuz Eylül Üniversitesi Hastanesi örnek yönetim modellemesi göstermiş ve bu kararları neticesinde Türkiye'de düşük oranda pozitif sağlık çalışanına sahip merkezlerden biri olmuştur.

Tablo 5: Vakaların sağlık çalışanı olma durumu.

\begin{tabular}{|l|c|c|c|c|}
\hline & \multicolumn{2}{|c|}{ 1. Dönem* } & \multicolumn{2}{c|}{ 2. Dönem** } \\
\hline Sağlık Çalışanı & N & $\%$ & $\mathbf{N}$ & $\mathbf{\%}$ \\
\hline Evet & 101 & 22.9 & $\mathbf{1 4 8}$ & $\mathbf{9}$ \\
\hline Hayır & 341 & 77.1 & $\mathbf{1 4 9 6}$ & $\mathbf{9 1}$ \\
\hline Toplam & 442 & 100 & $\mathbf{1 6 4 4}$ & $\mathbf{1 0 0}$ \\
\hline
\end{tabular}
**18.03.2020-24.04.2020 periyodu $18.03 .2020-13.09 .2020$ periyodu

Diğer taraftan, Şekil1'de 30-69 yaş gruplarında vaka oranlarındaki birinci ve ikinci dönemler arasında değişimin birbirine yakın seyrettiği, buna karşın 0-9, 10-19, 20-29 ve 80 ve üzeri yaș gruplarında dikkat çekici değișimler gözlenmiştir. Özellikle 0-9 yaş aralığında gözle görülür yüksek artıș, 80 ve üzeri yaş grubunda ise dikkat çeken bir azalış gözlenmiștir.

Tablo 6: Vakaların DEÜTF çalışanı olma durumu.

\begin{tabular}{|l|c|c|c|c|}
\hline & \multicolumn{2}{|c|}{ 1. Dönem } & \multicolumn{2}{c|}{ 2. Dönem } \\
\hline $\begin{array}{l}\text { DEÜTF } \\
\text { Çalışanı }\end{array}$ & $\mathrm{N}$ & $\%$ & $\mathbf{N}$ & $\mathbf{\%}$ \\
\hline Evet & 46 & 10.4 & $\mathbf{2 4 1}$ & $\mathbf{7 . 1}$ \\
\hline Hayır & 396 & 89.6 & $\mathbf{3 1 3 5}$ & $\mathbf{9 2 . 9}$ \\
\hline Toplam & 442 & 100 & $\mathbf{3 3 7 6}$ & $\mathbf{1 0 0}$ \\
\hline
\end{tabular}

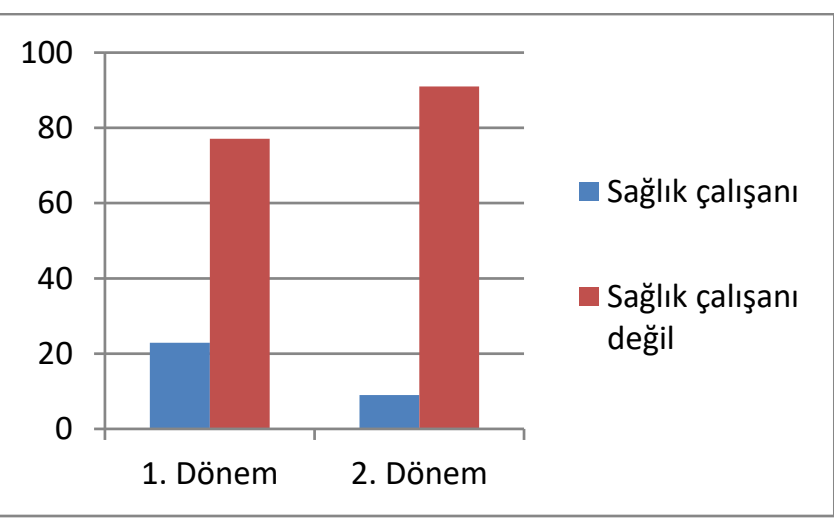

Şekil 2. Vakaların sağlık çalışanı olma oranları

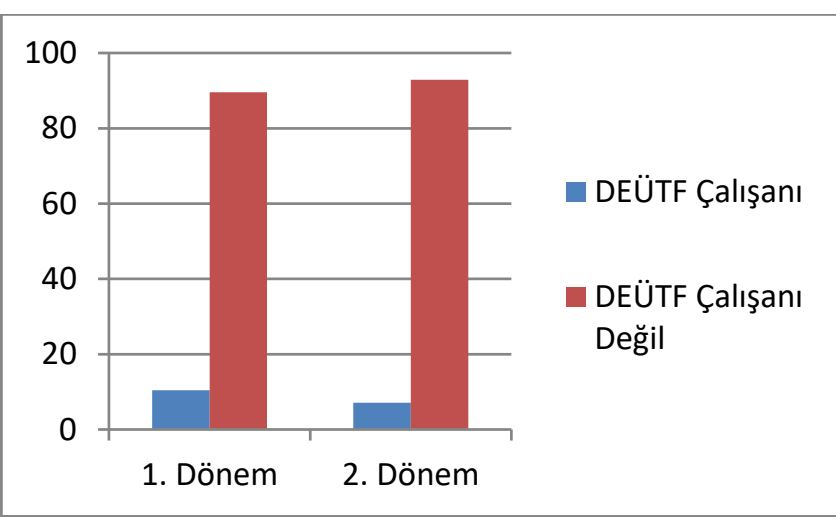

Şekil 3. Vakaların DEÜTF çalışanı olma oranı

Tablo7, Tablo8 ve Tablo9 göstermektedir ki, pandemi sürecinin başladığı ilk dönemde vakaların \%34.4 gibi önemli bir oranı huzurevi ile ilişkiliydi. Yine veriler incelendiğinde vakaların \%20.6'sının huzurevi sakini, $\% 12.2$ 'sinin ise huzurevi çalışanı olduğu görülmekteydi. Daha sonra alınan çok ciddi önlemler ve izolasyon kararları ile beraber 


\section{N. HOTAR, R.E. OMAY, S. BAYRAK, Z. KURUÜZÜM, B. ÜNAL}

normalleșme dönemi dahil olmak üzere huzurevinde yeni vakaya neredeyse hiç rastlanmamış (Mayıs ayından beri sadece iki vaka) olması çok önemlidir.

Tablo 7: Vakaların huzurevi ile ilgili olma durumu.

\begin{tabular}{|l|c|c|c|c|}
\hline & \multicolumn{2}{|c|}{ 1. Dönem* } & \multicolumn{2}{c|}{ 2. Dönem** } \\
\hline $\begin{array}{l}\text { Huzurevi ile } \\
\text { ilișkili olması }\end{array}$ & $\mathbf{N}$ & $\%$ & $\mathbf{N}$ & $\mathbf{\%}$ \\
\hline Evet & 152 & 34.4 & $\mathbf{1 5 8}$ & $\mathbf{9 , 6}$ \\
\hline Hayır & 290 & 65.6 & $\mathbf{1 4 9 2}$ & $\mathbf{9 0 , 4}$ \\
\hline Toplam & 442 & 100 & $\mathbf{1 6 4 4}$ & $\mathbf{1 0 0}$ \\
\hline
\end{tabular}
**18.03.2020-24.04.2020 periyodu $18.03 .2020-13.09 .2020$ periyodu

Tablo 8: Vakaların huzurevi sakini olma durumu.

\begin{tabular}{|l|c|c|c|c|}
\hline & \multicolumn{2}{|c|}{ 1. Dönem* } & \multicolumn{2}{c|}{ 2. Dönem** } \\
\hline $\begin{array}{l}\text { Huzurevi } \\
\text { sakini }\end{array}$ & $\mathrm{N}$ & $\%$ & $\mathbf{N}$ & $\mathbf{\%}$ \\
\hline Evet & 91 & 20.6 & $\mathbf{9 3}$ & $\mathbf{5 . 7}$ \\
\hline Hayır & 351 & 79.4 & $\mathbf{1 5 5 1}$ & $\mathbf{9 4 . 3}$ \\
\hline Toplam & 442 & 100 & $\mathbf{1 6 4 4}$ & $\mathbf{1 0 0}$ \\
\hline
\end{tabular}
** 18.03.2020-24.04.2020 periyodu
* 18.03.2020-13.09.2020 periyodu

Tablo 9: Vakaların huzurevi çalışanı olma durumu.

\begin{tabular}{|l|c|c|c|c|}
\hline & \multicolumn{2}{|c|}{ 1. Dönem* } & \multicolumn{2}{c|}{ 2. Dönem* } \\
\hline $\begin{array}{l}\text { Huzurevi } \\
\text { çalışanı }\end{array}$ & N & $\%$ & N & \% \\
\hline Evet & 54 & 12.2 & $\mathbf{5 6}$ & $\mathbf{3 . 4}$ \\
\hline Hayır & 388 & 87.8 & $\mathbf{1 5 8 8}$ & $\mathbf{9 6 . 6}$ \\
\hline Toplam & 442 & 100 & $\mathbf{1 6 4 4}$ & $\mathbf{1 0 0}$ \\
\hline * 18.03.2020-24.04.2020 periyodu \\
** 18.03.2020-13.09.2020 periyodu
\end{tabular}

Hem yaşlı nüfusu yoğun șekilde barındırması hem de kronik hastalıklar sebebiyle huzur evleri, hastalığa yakalanma ve hastalığın ağır seyretme riskinin yüksek olduğu mekanlardır. Pandeminin yaşandığı ülkelerde Covid-19 sebebiyle yaşanan kayıpların büyük oranda yaşlıların bir arada kaldığı kuruluşlarda görülmesine karşın, T.C. Aile Çalışma ve Sosyal Hizmetler Bakanlığı Engelli ve Yaşlı Hizmetleri Genel Müdürlüğü'nün (ailevecalısma.gov.tr, 2020) erken dönemde ve ilk Covid-19 vakasının Türkiye'de görülmesinden sonraki süreçte almış olduğu önlemlerle, Türkiye' de huzurevleriyle ilişkili vakalar diğer ülkelere göre düşük oranlarda seyretmektedir (Hotar vd., 2020).

Türkiye'de genel nüfus içindeki yaşlıların (65 yaş ve üstü) oranı, daha yüksek ölüm oranlarına sahip ülkelere kıyasla daha düşük olmasına rağmen, yaşlıları korumak ve enfeksiyonun yayılmasını önlemek için erken dönemde özel önleyici tedbirler alınmıştır. Yaşlılar ve kronik rahatsızlı̆̆ olan insanlar için erken dönemde uygulanan sokağa çıkma yasağı onları virüse maruz kalmaktan korumuştur. Dolayısıyla, Türkiye, özellikle 65 yaş üstü nüfus (yüksek risk grubu) açısından en düşük ölüm oranlarından birine sahiptir (apps.who.int, 2020).

1. dönem zaman periyodunda, yurtdışı seyahat öyküsü olan kesin Covid-19 vakalarının oranının \%1.6 olduğu görülmüștür (Hotar vd., 2020). Ülkemizde, yurtdıșı seyahatleri ile ilgili ilk tedbir 24 Ocakta Wuhan-İstanbul uçuşlarının durdurulması ile başlamıştır. Ardından, 4 Şubatta Covid-19 vakalarının görüldüğü ülkelerden gelen yolcuların hava alanlarinda termal kameralar ile kontrol edilmesi ve 5 Şubatta Çin-İstanbul arasındaki tüm uçuşların durdurulması kararları alınmıștır. 23 Şubatta Türkiye-İran kara hudut kapılarının kapatılmış ve ayrıca 29 Şubatta İtalya, Güney Kore, Irak arasındaki uçuşlar durdurulmuștur.

T.C. Ulaştırma ve Altyapı Bakanlığı 14.03.2020 tarihinde pandemi tedbirleri kapsamında Türkiye'den Almanya, Fransa, İspanya, Norveç, Danimarka, Belçika, Avusturya, İsveç ve Hollanda, Azerbaycan ve Gürcistan'a düzenlenen uçuşları askıya aldığını (www.uab.gov.tr, 2020a), 21.03.2020 tarihinde yapmış olduğu basın açıklaması ile Türkiye'nin 68 ülke ile uçuş trafiğini kapattığını duyurmuştur (www.uab.gov.tr, 2020b).

Umreden gelen kafileler tahsis edilen yurtlarda gözlem altına alınarak, turistik amaçlı yurtdışında olan ya da yurtdışında öğrenimini sürdüren vatandaşlarımızın karantina şartı ile ülkeye girişi sağlanmıştır. 
Alınan tedbirlerin söz konusu yurtdışı seyahat öyküsü oranının düşük olmasında etkili faktörler olduğu değerlendirilmiştir (Hotar vd, 2020),

Normalleşme süreci ile beraber, yurtdışı hareketi ile birlikte yurtdışı temas hikayesi Sağlık Bakanlığı tarafından kriter olarak değerlendirilmediği için bu çalışmanın da izlem kriterlerinden biri olmaktan çıkarılmıştır.

Nisan aylarında kesin Covid-19 vakalarının \%67 gibi büyük bir oranda bilinen Covid-19 vakası ile teması bulunmaktaydı. Normalleşme süreci ile birlikte her ne kadar bu anamnez verisinin tespiti daha büyük güçlükler içerse de tanı konulan vakaların neredeyse \%70'inde temas öyküsü net olarak tespit edilebilmektedir. $\mathrm{Bu}$ oran pandeminin yayılımını kontrol altına almak için alınan önlemlerin ve sosyal, bir diğer ifade ile fiziksel izolasyonun önemini ortaya koyan bir değerdir. Ayrıca ülkemizde çok sıkı şekilde uygulanan filyasyon çalışmalarının önemini de ortaya koymaktadır. Bununla birlikte çalışmanın örneklem grubunda takip edilen pozitifleşen Dokuz Eylül Üniversitesi çalışanlarının filyasyon çalışmalarında neredeyse bir vaka başına yaklaşı 15 temaslının tespit edilmesi çok önemlidir. Bu durum özellikle normalleşme takvimi ile beraber vatandaşlarımızın izolasyon ve mesafe kurallarına riayette güçlük yaşadığını göstermektedir. Pandemi ile mücadelenin başarıya ulaşmasında en kritik noktalardan biri olan bu durum aslında mücadelenin başarılmasının da yolunu göstermektedir. Vaka/temaslı oranının olabildiğince azaltılması, vaka eğrilerini tersine döndürecek ve gerçek normale dönmemizi sağlayacaktır. Bunu başarabilmek için vatandaşların geleneksel ve sosyal medya gibi araçlar ile bilgilendirilmesine devam edilmeli, sağlı otoriteleri tarafından yapılan açıklamalara itibar edilmesi ve uyulması gerektiği sürekli hatırlatılmalıdır.

Bir diğer önemli husus da risk grubunda yer alan bireylerin veya hastalığı taşıyan, ancak hafif seyir etmesi nedeni ile evden gözlemlenen bireylerin süreç içerisinde resmi makamlarca olușturulmuș yardım gruplarından destek almalarının da teşvik edilmesidir. Her ne kadar ülkemizde birbiri ile yardımlaşma kültürü yaygın olsa da, özellikle şahsen tanışılmayan bireylerden veya kurumlardan yardım talebinde bulunmaktan kaçınılabileceği göz önünde bulundurulmalı, yardım talep etmenin özellikle böyle bir dönemde bireyin sadece kendisi için değil, çevresi için de hayat kurtarıcı olabileceği vurgulanmalıdır (Hotar vd., 2020).

Tablo 10. Ülkelere göre Covid-19 vakaları ve ölümler*

\begin{tabular}{|l|c|c|c|c|}
\hline & $\begin{array}{c}\text { Toplam } \\
\text { Vaka }\end{array}$ & $\begin{array}{c}\text { Toplam } \\
\text { Vaka } * *\end{array}$ & $\begin{array}{c}\text { Toplam } \\
\text { Ölüm }\end{array}$ & $\begin{array}{c}\text { Toplam } \\
\text { Ölüm** }\end{array}$ \\
\hline İngiltere & 590848 & 8704 & 42760 & 630 \\
Fransa & 691368 & 10592 & 32449 & 497 \\
İspanya & 861112 & 18418 & 32929 & 704 \\
İtalya & 349494 & 5780 & 36140 & 598 \\
Hollanda & 168082 & 9809 & 6558 & 383 \\
Türkiye & 334031 & 3961 & 8778 & 104 \\
Romanya & 152403 & 7922 & 5358 & 279 \\
Rusya & 1298718 & 8899 & 22597 & 155 \\
\hline
\end{tabular}

* Kaynak: DSÖ 20 Ekim 2020 verileri

** 1 Milyon Nüfus Başına

Dünya Sağlık Örgütü'nün 20 Ekim 2020 tarihinde vermiş olduğu DSÖ bölgelerine göre Avrupa Bölgesi'nde doğrulanmış Covid-19 vaka sayıları incelendiğinde, 1 milyon nüfus başına toplam vaka sayısı 3961, 1 milyon nüfus başına toplam ölüm sayısı 104'dür. Hem vaka sayısı hem de ölüm sayısı bakımından Tablo 10'da yer alan ülkeler arasında en düşük olan ülkenin gözle görülür bir farklılıkla Türkiye olduğu görülmektedir. Bu başarının en büyük sebebi Türkiye'nin pandemi konusunda oldukça erken bir dönemde, hızla ve kararlılıkla tedbir almasıdır.

Dünya Sağlık Örgütü 11.06.2020 tarihinde yayınlamış olduğu raporda, kararlılıkla uygulanan tedbirler ve çok sektörlü yaklaşım sayesinde Türkiye'nin Covid-19 mücadelesinde elde edilen başarıdan ve Türkiye'nin şimdiye kadarki deneyiminin Dünyaya ve bölgeye bu yeni virüsle mücadelede benzersiz bir firsat ve 
ayırt edici iç görüler sağladığından detaylı bir şekilde bahsetmiştir. Raporda, Türkiye'nin en zengin ülkeler arasında olmamasına rağmen salgınla mücadelede en cömert davranan ülkelerden biri olduğu vurgulanmıștır. Türkiye, bilimsel yaklaşımla salgının hızla kontrol altına alınmasının, ölüm oranlarının dünya ortalamasının altında kalmasında etkili olduğu dikkat çeken diğer noktadır (apps.who.int, 2020).

21 Nisan 2020 tarihli TÜBA Covid-19 Pandemi Değerlendirme Raporu'na göre aktif vaka sayısındaki büyüme oranını gösteren büyüme hızı Türkiye için pozitif bölgede idi ve hala pozitif bölgede olmasına karşın büyüme hızında sürekli bir düşüş gözlenmekteydi. 24 Nisan itibari ile büyüme hızı negatif bölgeye düşmüștür ve 4 Haziranda tekrar pozitif bölgeye geçmiştir. Zaman içinde büyüme hızındaki sürekli düşüş ve bu oranı negatif bölgede tutmak kontrollü ilerleme olduğunu gösterecektir (www.tuba.gov.tr, 2020). Bu düşüşün sağlanabilmesi için vatandaşların gerek çalışma hayatında gerekse sosyal ortamlarda alınan tedbirlere, sosyal mesafe kurallarına, kişisel hijyene dikkat etmesi gerekmektedir. $\mathrm{Bu}$ süreçte maske takmanın önemi de unutulmamalıdır.

Pandeminin başında Dokuz Eylül Üniversitesi Araştırma Uygulama Hastanesi kesin Covid-19 vakalarının \%26,9 gibi büyük bir oranını emekliler oluşturmaktaydı. Bu yüksek oran aynı zamanda vakaların önemli bir oranının huzurevi sakini olması ile de açıklanabilirdi. Sürecin ilerlemesi ve diğer tüm meslek gruplarının aktif yaşama dönmesi, daha da önemlisi sosyal izolasyon kurallarına riayet edilmemesi sonucunda meslek grupları arasındaki farklılıklar ortadan kalkmıștır. Emeklilerin söz konusu yüksek oranı yukarıda bahsedilen önlemler sonucunda Huzurevlerinin pandemi açısından kontrol altına alınması ile ciddi oranda düșmüștür. Tablo 5 ve Şekil 2' de görüldüğü gibi, önceki döneme göre düşük oranlarda seyretmesine rağmen, sağlık çalışanlarında pozitif vaka görülmesi durumu ne yazık ki güncelliğini devam ettirmektedir. Fakat unutulamamalıdır ki, DEÜ örneğinde olduğu gibi iyi süreç yönetimi ile bu oran da sürekli olarak kontrol edilebilir düzeylerde tutulabilmektedir. Elbette ki normalleşme dönemi ile beraber toplu çalışılan işyerlerindeki pozitif vaka oranları nedeniyle bu tablolardaki oranlar birbirine çok yaklaşmış ve istatistiksel olarak anlamlı farklılıklar gözlenmez olmuştur.

\section{NORMALLEŞME SÜRECINDE PANDEMINNIN TOPLUMSAL VE EKONOMIKK ETKİLERİ}

Bir toplumun en temel ihtiyaçlarından birinin sağlık hizmetleri olduğu gerçeği Covid-19 pandemisi ile birlikte bir kez daha karşımıza çlkmıştır. DSÖ’nün de övgüyle bahsettiği gibi, Türkiye'nin bu süreci diğer ülkelere de örnek olacak bir başarıyla yürütmesinde Sağlık Bakanlığg'nın 2003 yılında "Önce İnsan" sloganıyla başlattı̆̆ı Sağlıkta Dönüşüm Programı'nın katkısı çok büyüktür. Bu program çerçevesinde gerçekleştirilen reformlar ile ve son 18 yılda sağlık alanında yapılan atılımlar ile Türkiye, pandemiye hazırlıklı ve yeterli ülkelerden birisi olmuştur. Donanımlı hastaneler, yüksek sayıda yatak kapasiteleri, sağlık hizmetlerine erişim kolaylığı, genel sağlık sigortası kapsamında vatandaşların neredeyse tamamının devlet sigortası ile ücretsiz sağlık hizmeti güvencesinin varlığı, yetişmiş sağlık personeli, karantina süreçlerinin doğru yürütülmesi, zamanında teşhis sürecin başarılı ve etkin bir şekilde yönetilmesinde öne çıkan unsurlardır. Sağlık Bakanlığı'nın 30.09.2020 yılında yayınladığı Sağlık İstatistikleri Yıllığında, 2019 yılı itibariyle ülkemizde 1538 hastane vatandaşlarımıza hizmet vermektedir ve bu hastanelerde 160810 hekim, 198103 hemşire ve 55972 ebe görev yapmaktadır. Hastanelerimizin toplam yatak kapasitesi 237504 ve yoğun bakım yatak sayısı 39955'dir (dosyamerkez.saglik.gov.tr, 2020).

Coronavirüs aşı çalışmalarıyla ilgili olarak da Türkiye'de önemli adımlar atılmaktadır. İçerisinde İzmir Biyotıp ve Genom Merkezinin de bulunduğu birçok üniversitede aşı 
çalışmalarına devam edilmektedir ve bu çalışmalarının ikisinde hayvan deneyleri başarıyla gerçekleştirilmiştir. TUBITTAK bünyesinde yürütülen 10 ilaç ve 8 aşı geliştirme projesinde 49 kuruluşla iş birliği yapılmaktadır ve yerli Covid-19 aşısının 2021 Nisan'a kadar piyasaya sürülmesi hedeflenmektedir.

Bilişim, dijital teknolojiler ve sosyal medya pandeminin birinci döneminde olduğu gibi ikinci döneminde de ülkemizde etkin şekilde kullanılan ve pandeminin nasıl üstesinden gelindiğinin, normalleşme sürecindeki gelişmelerin ve alınması gereken tedbirlerin ve gerekli uyarıların aktarıldığı alanlar olmaya devam etmektedir. Normalleşme sürecinde dijital teknolojilerin kullanıldığı en önemli uygulama "Hayat Eve Sığar" uygulamasıdır. Pandemiyle mücadele döneminde bilişim ve teknolojinin sunduğu imkânlardan en üst düzeyde faydalanan ve tüm süreci sağlık bilişim sistemleri üzerinden kontrol ve takip eden Sağlık Bakanlı̆̆l, Hayat Eve Sığar (HES) uygulaması ile bu kontrol ve takibi vatandaşların da hizmetine sunmuştur. Hayat Eve Sığar uygulaması ile vatandaşlar, yaşadıkları bölgede ya da gitmek istedikleri lokasyondaki risk durumunu ve hastalık yoğunluğunu harita üzerinden görebiliyor, risk yoğunluğunun yanı sıra, hastane, eczane, market, duraklar gibi acil ihtiyaçlarda bilinmesi gereken yerler de vatandaşlara gösteriliyor. Geliștirilen akıllı algoritmalar sayesinde, uygulamada yakınlarının onayları doğrultusunda ailelerini ya da yakınlarını listelerine ekleyebilen vatandaşlar, onların da riskli bölgelerden uzak durmalarını sağlayabilmektedir. Türkiye Günlük Koronavirüs tablosunu da uygulamadan inceleyebilmekte, seyahatlerinde kullandıkları HES Kodu'nu uygulamadan alabilmektedirler (web.archive.org, hayatevesigar.saglik.gov.tr, 2020). HES uygulaması geliştirildikten sonra Covid-19 tedbirleri kapsamında İçişleri Bakanlığ tarafından yayımlanan genelge gereğince 12 Eylül 2020 tarihinden itibaren Türkiye'de şehirlerarası otobüslerde HES kodu zorunluluğu getirilmiş ve bu düzenlemeden hemen sonra ise 23 Eylül 2020 tarihi itibariyle yine İçişleri Bakanlığı tarafından yayımlanan bir genelgeyle tüm Türkiye'de kamu kurumlarına girişlerde HES kodu zorunluluğu getirilmiștir (www.icisleri.gov.tr, 2020b, 2020c).

Sağlık Bakanı Fahrettin Koca'nın 11.03.2020 tarihinde Türkiye' de tespit edilen ilk vaka açıklamasını yapmasının hemen ardından 16.03.2020 tarihinden itibaren ilkokul, ortaokul ve lise eğitimine bir hafta, üniversitelerde ise üç hafta ara verildiği açıklanmıştır. 23.03.2020 tarihinden itibaren televizyon ve internet aracılı̆̆ıla uzaktan eğitime geçilme kararı alınmış olup, aynı tarihte üniversiteler tarafından üretilen dijital ders içerikleri YÖK Dersleri Platformu (Yükseköğretim Kurumları Dersleri) adı verilen web ara yüzünde üniversite öğrencilerinin açık erişimine sunulmuştur. 23.03.2020'de Milli Eğitim Bakanlığı (MEB) ve Türkiye Radyo Televizyon Kurumu işbirliği ile TRT EBA TV yayınlarına başlamış olup Milli Eğitim Bakanı Ziya Selçuk 25 Mart'ta örgün eğitimde verilen aranın 30 Nisan'a kadar uzatıldığını açıklanmıștır. Hemen ardından 26.03.2020 tarihinde YÖK Başkanı Yekta Saraç, Covid-19 pandemisi tedbirleri kapsamında üniversitelerde bahar döneminde yüz yüze eğitim yapılmayacağını ve eğitim öğretim sürecinin sadece uzaktan eğitim, açı öğretim ve dijital öğretim imkanları ile sürdürüleceğini açlklamıştır. 1 Nisan'da YÖK koronavirüs salgını nedeniyle ön lisans, lisans ve lisansüstü düzeyde öğrenim gören öğrencilerin talep etmeleri halinde 2019-2020 eğitim öğretim yılı bahar döneminde kayıtlarını dondurabilmesine; tez savunma ve yeterlik sınavlarının ise denetlenebilir olma ve "kayıt altına alınmak şartıyla" video konferans gibi dijital imkanlar ile yapılabilmesine olanak sağladığını açıklamıştır. Bu süreçte YÖK tarafindan https://yokdersleri.yok.gov.tr adresinden öğrencilerin ulaşabilecekleri üniversitelere ait içeriklere, mobil operatörleri tarafından hatlarına ücretsiz olarak tanımlanacak olan 6 GB'lık "Uzaktan Eğitime Destek" kotası kapsamında erişebilme imkanı sağlanmıştır. $\quad 18.05 .2020 \quad$ tarihinde 
Cumhurbaşkanı Recep Tayyip Erdoğan 20192020 eğitim-öğretim döneminin sona erdiğini açıklanmıştır. 12 Ağustos'ta Milli Eğitim Bakanı Ziya Selçuk 31 Ağustos 2020 tarihinde okulların uzaktan eğitimle açılacağını ve 21 Eylül'de Bilim Kurulu tarafından tavsiye edilen sınıflarda aşamalı ve seyreltilmiş şekilde yüz yüze eğitiminin de başlayacağını, okullar açıldığında öğrencilere, öğretmenlere, okulların destek personeline, servis sürücülerine varana kadar okullarla ilgili herkesin sağlık durumunun HES kodları marifetiyle takip altında olacağını açıklamıştır.

Ülkemizde pandemi sürecinde eğitime yönelik alınan yukarıdaki tedbirler ve kararlarda eğitimin dijital ve uzaktan eğitimle gerçekleştirilmesi üzerinde odaklanılmış ve bu durum, bilginin günümüzde aslında kolay erişilebilir olması gerçeğini ortaya koymuştur. Bu süreçte MEB ve YÖK'ün aldığı kararlarla tüm okulların uzaktan eğitime geçmesi ile birlikte birçok ders içeriğinin yanı sıra araștırmalar, bilimsel çalışmalar, makaleler, kitaplar çevrimiçi ortamda ücretsiz olarak sunulmaya başlanmıştır. $\mathrm{Bu}$ durum, bireylerin bilgi kaynaklarına daha kolay erişebilmesini olanaklı kılmıştır (Hotar vd., 2020).

Covid-19 pandemisi ile ve devamında normalleşme sürecinde uzaktan erişime geçme süreci sadece eğitimde değil iş dünyasında da zorunlulukların da bir sonucu olarak hızlı bir şekilde benimsenmiştir. $\mathrm{Bu}$ süreç, iş yaşamındaki vatandaşların neredeyse tamamının uzaktan erişime alışmasını ve adapte olmasını sağlamıştır. Nitekim 22 Mart 2020 tarihinde Resmi Gazete'de yayımlanan genelge ile kamuda ihtiyacı karşılayacak kadar asgari personelin bulundurulması şartıyla, kamu kurum ve kuruluşlarında çalışanlara, uzaktan çalışma, dönüşümlü çalışma gibi esnek çalışma yöntemlerinin uygulanabilmesine imkan verilmiştir. Dönüşümlü, esnek ve uzaktan çalışma uygulamasına 1 Haziran 2020 tarihinde son verilmiş, 26 Ağustos'ta Cumhurbaşkanlığı tarafından yayımlanan genelgeyle tekrar izin verilmiştir. $\mathrm{Bu}$ süreç kamuda ve özel sektörde online toplantılar, konferanslar, söyleşiler vb. mekandan bağımsız yeni bir yaşam ve çalışma sisteminin hızlı bir şekilde hayatımıza girmesine sebep olmuştur. Her ne kadar pandemiden kaynaklanan sebeplerle zorunluluk olarak karşımıza çıksa da esnek ve uzaktan çalışma, iş yeri maliyetlerinin azaltılması, mekandan bağımsız olması, zaman konusunda esnek olması gibi avantajlara sahip olması sebebiyle pandemi sonrasinda da dijitalleşmenin artması ile birlikte tercih edilir hale gelme eğilimindedir. $\mathrm{Bu}$ durum yeni teknolojilerin geliştirilmesi için büyük firsatlar doğurmakla birlikte, özellikle aktif olarak çalışma hayatı içerisinde yer alan bireylerin dijital dönüşüm için daha yetkin ve donanımlı olabilmek amacıyla bugünden gerekli hazırlıkları yapmaları gerektiğini de gözler önüne sermiştir (Hotar vd., 2020).

$\begin{array}{lrrrr}\text { Avrupa İstatistik } & \text { Ofisi (Eurostat) } 2018 \\ \text { verilerine } & \text { göre } & \text { Avrupa Birliği(AB) }\end{array}$ vatandaşlarının \%5.2'si evden çalışmaktadır. Söz konusu dönemde, AB üyesi 27 ülke arasında evinde çalışanların oranının en yüksek olduğu ülke \%14 ile Hollanda'dır. Türkiye'de ise bu oran \%2.2'dir. AB'de kadınlar erkeklere göre daha yüksek oranda evden çalışma gerçekleştirmektedir (Şeker A.U., 2020).

Pandemi sona erdiğinde eğitim ve iş dünyasında dijitalleşme daha da gelişecektir. Buna karşın uzaktan eğitim ve evden çalışma pandemi sürecinde olduğu gibi hızlı bir yükseliş içerisinde olmayacaktır. Eğitimde örgün eğitim ile uzaktan eğitimin birlikte kullanıldı̆̆ı hibrit yapılar daha çok gündeme gelirken, iş dünyasının bu süreci bir müddet daha deneyimlemesi, tecrübelenmesi ve kurum kültürünün buna hazır hale getirilmesi, dijital dönüşüme hız kazandırılması ve yeni çalışma modelleri üretilmesi gerekmektedir. Nitekim eğitimde her alan ve iş dünyasında her sektör uzaktan çalışmaya uygun değildir.

Salgın küresel ölçekte arz ve talebin önemli ölçüde daralmasına, tedarik zincirlerinin aksamasına, küresel ticaret hacminin gerilemesine ve işsizlik oranlarının yükselmesine neden olmuştur. Turizm ve 
ulaştırma sektörleri bu süreçte görece daha fazla etkilenen sektörler olarak ön plana çıkmıştır (ms.hmb.gov.tr, 2020). Türkiye'ye 2019 yılında 51 milyon turist gelmiş 34.5 milyar dolar gelir elde edilmişken bu yılın ilk yedi ayında 5.5 milyon turist gelmiştir. Turizm sektöründe aşı bulunsa da psikolojik nedenlerle seyahat etmenin önümüzdeki yıllarda da azalacağı öngörülmektedir(Zengin, 2020). Salgın, ayrıca özellikle Mart ve Nisan aylarında, finansal piyasalarda dalgalanmalara, gelişmekte olan ülkelerden sermaye çıkışlarına ve bu ülkelerde uluslararası döviz likiditesinde azalmaya yol açmıștır (ms.hmb.gov.tr, 2020).

Üretim, ihracat ve istihdamın devamlılı̆g 18 Mart 2020 tarihinde açlklanan Ekonomik İstikrar Kalkanı Paketi ile desteklenmiştir. Paketin kapsamı daha sonra ortaya çıkan ihtiyaçlar doğrultusunda alınan yeni tedbirler ile genişletilmiş, böylece toplumun tüm kesimlerinin bu süreçte desteklenmesi sağlanmıştır.

Ekonomik İstikrar Kalkanı Paketi ve alınan diğer tedbirler kapsamında, ihtiyaç sahibi hane halkına nakit desteği sağlanmış, en düşük emekli aylığı yükseltilmiş, kısa çalışma ödeneğinin kapsamı genişletilerek süresi uzatılmış, telafi çalışma süresi artırılmış, istihdamın sürekliliği desteklenmiș ve bireylerin krediye erişim imkânları artırılmıştır. İşletmelerin vergi ve prim ödemeleri ertelenmiş, işletmelere sektörel odaklı vergi indirimleri yapılmış, kredi ödemelerinin ertelenmesi imkânı tanınmış, temerrüde düşen firmalara mücbir sebep açıklama imkânı getirilmiş ve kredi teşvikleri verilmiş, Kredi Garanti Fonu'nun (KGF) limiti artırılarak teminat sıkıntısı yaşayan işletmelerin finansmana erişimine imkân sağlanmıștır (www.aa.com.tr, 2020a). Covid-19 sürecinde bugüne kadar atılan adımların toplam tutarı 260 Milyar TL'ye ulaşmıştır (www.hmb.gov.tr, 2020). 5.5 Milyon aileye 1000 TL'lik nakdi destek sağlandı. Kısa çalışma ödeneği, işsizlik ödeneği, nakdi ücret desteği kapsamında 4.5 milyonu aşkın vatandaşa 6 milyar TL kaynak aktarıldı (www.aa.com.tr, 2020b). .

Türkiye İstatistik Kurumu'nun 12 Ekim 2020 tarihinde yayınladığı Haziran, Temmuz ve Ağustos aylarını kapsayan işgücü istatistiklerine göre, işsizlik oranı 0,5 puanlık azalış ile \%13,4 seviyesinde gerçeklești. Tarım dışı işsizlik oranı 0,6 puanlık azalış ile \%15,9 oldu. İstihdam oranı ise 2,9 puanlık azalış ile $\% 43,5$ oldu. Bu dönemde, istihdam edilenlerin sayısı tarım sektöründe 361 bin, sanayi sektöründe 246 bin, hizmet sektöründe 761 bin kişi azalırken inşaat sektöründe ise 114 bin kişi arttı. İstihdam edilenlerin \%19,4'ü tarım, $\% 19,6$ 'sı sanayi, \%6,1'i inşaat, $\% 54,9$ 'u ise hizmet sektöründe yer aldı (tuikweb.tuik.gov.tr, 2020). Covid-19 pandemi döneminden en çok etkilenen sektörlerden biri olan hizmet sektöründe istihdam oranı diğer sektörlere göre daha büyüktür ve dolayısıyla özellikle hizmet sektörüne yönelik istihdam politikaları geliştirilmesi son derece önem taşımaktadır.

TÜBA'nın raporuna göre pandeminin Türkiye ekonomisi üzerindeki etkileri açısından bakıldığında, Avrupa ve Afrika pazarlarına Amerika pazarlarını da eklemek bir kazanım olacaktır (www.tuba.gov.tr, 2020). Nitekim uluslararası danışmanlık şirketi Kearney, “Türkiye'yi Geleceğin Küresel Değer Zincirlerinde Konumlandırmak" adlı raporunda, pandemi sonrası değişimlerden en çok fayda sağlayacak ülkelerden birinin Türkiye olduğunu belirtmektedir. Türkiye'nin bu süreçte öne çıkmasını sağlayacak faktörlerden birisi, salgının etkisiyle tedarik zincirlerinin kısalması ve Avrupa ülkelerinin Türkiye gibi yakın yerlerde üretim yaptırmayı tercih edecek olmasıdır. Raporda iyimser senaryoda pandemi sonrası dönemde Türkiye'nin toplam ihracatının yıllık 16 milyar dolar artış göstereceği tahmin edilmektedir. Muhafazakar senaryoda ise bu artışın 10 milyar dolar olması beklenmektedir (www.deik.org.tr, 2020). 


\section{N. HOTAR, R.E. OMAY, S. BAYRAK, Z. KURUÜZÜM, B. ÜNAL}

\section{SONUÇLAR}

PROBEL kayıtlarına göre, 18.03.202015.11.2020 tarihleri arasında sistemde Sağlık Bakanlığı'nın U07.03 kodu ile bildirim istediği Covid-19 olası tanılı hastalarda yapılan PCR taramaları sonucunda 3376 hasta kesin vaka olarak tanımlanmıştır. Çalışmada bu periyot 2 . Dönem olarak ifade edilmiştir ve vakaların cinsiyete göre dağılımı, yaş durumu, yaş gruplarına göre dağılımı, onlu yaş gruplarına göre dağılımı ve DEÜTF çalışanı olma durumları söz konusu dönemde tespit edilen 3376 vaka için incelenmiştir. Fakat veriye ulaşım açısından, vakaların sağlık çalışanı olma durumu, huzur evi ile ilişkisi, huzurevi çalışanı ve huzurevi sakini olma durumlarl ise 18.03.2020-13.09.2020 periyodunda 1644 hasta için incelenmiş ve bu dönem de 2 . Dönem olarak isimlendirilmiştir. Söz konusu değişkenler için hem 1 . dönem hem de ikinci dönem verileri göz önünde bulundurulduğunda aşağıdaki sonuçlara ulaşılmıştır.

- Hem 1. dönemde hem de ikinci dönemde cinsiyetin Covid-19 virüsüne yakalanma riski üzerinde doğrudan belirleyici bir etkisi olmadığı söylenebilir. Vakaların yaş ortalaması 19.6 standart sapma ile 41.2 olarak gözlenmiștir.

- Normalleşme süreci ile birlikte 18 yaş altı nüfusta Covid-19 vakası görülmesi oranı yaklaşık \%3'den \%11'e yükselmiştir. Buna karşın 65 yaş ve üzeri grupta Covid-19 vakası görülmesi oranı yaklaşı \%30'dan \%13'e düșmüștür. Aktif çalıșma hayatının içinde bulunan 18-64 yaş arası grupta ise Covid-19 vakası görülmesi oranı daha da artarak \%68'den \%76'ya yükselmiştir.

- Vakaların huzur evi sakini olma oranı yaklaşık \%21'den \%6'ya düşmüştür.

- Hasta grubunun yapılan detaylı yaş analizinde neredeyse her yaş grubunda hasta görülmekle beraber, normalleşme süreciyle birlikte kümelenmenin en çok 30-40 yaş aralığındaki toplumun üretken ve aktif kesiminde olduğu tespit edilmiştir. $\mathrm{Bu}$ hasta grubunun yapılan anamnez değerlendirmesinde neredeyse tamamının aktif ve pandemi sırasında çalışıyor olduğu tespit edilmiştir.

- Normalleşme takvimi ile beraber iş yerlerinin açılması ve sosyal ortamlardaki iletişimin artmasıyla birlikte 30-50 yaş grubunda başlangıçta daha çok sağlık çalışanlarında görülen kümelenme neredeyse tüm meslek gruplarını etkilemeye başlamıştır. Şu an itibariyle aktif çalışan bu hasta grubun \%9'luk kısmı sağlık çalışanlarıdır ve vakaların \%7'si ise DEÜTF çalışanıdır.

- 0-9 yaş aralığında Covid-19 vakası görülmesi oranı yükselerek $\% 0.5$ 'den $\% 5.1$ 'e çıkmış, buna karşın 70 ve üzeri yaş grubunda oran \%26.5'den \%9.2'ye düşmüştür.

- Normalleşme döneminde huzurevinde yeni vakaya neredeyse hiç rastlanmamıştır. Huzurevlerinin izolasyon konusunda İzmir örneği ve bu noktada kurumlar arası iletişim pandemi mücadelesinin en önemli basamaklarından birini oluşturmuş ve ölümlerin azalmasında son derece belirleyici olmuştur.

Normalleşme sürecinde de tıpkı pandemi sürecinin başlangıcında olduğu gibi, büyük fedakarlıklarla görevlerini yapan sağlık çalışanları desteklenmeye devam edilmeli, ekipman ve ortamları sunmakta oldukları hizmetleri en düşük riskle yerine getirmelerini sağlayacak şekilde kurgulanmalıdır. $\mathrm{Bu}$ kurgunun oluşturulmasında bilimsel komisyonlar kurarak, kararlarını konsensuslarla alarak sahaya yansıtan ve süreç yönetimini proaktif stratejilerle yürüten Dokuz Eylül Üniversitesi'nin dikkat çekici olumlu bir örnek olarak değerlendirilmesi mümkündür.

Normalleşme süreci ile birlikte kademeli serbestleşme, özellikle okulların çok kontrollü açllyyor oluşu pandeminin kontrol altında 
tutulması noktasında çok büyük önem arz etmektedir. Aşamalı geçiş modeli sayesinde asemptomatik bulaştırıcılık insidansının en yüksek olduğu bilinen çocuk ve genç nüfus kontrol altında tutulmakta, bu durum da risk gruplarının yașamına yașam katmaktadır. Bu süreçte çocuk ve genç nüfusun özellikle sosyal mesafe, maske kullanımı ve hijyen konusunda sürekli bilinçlendirilmesi çok önemlidir.

Pandemi süreci ile birlikte eğitim kurumlarının altyapılarını geliştirerek uzaktan eğitim sistemini son derece etkin bir şekilde hayata geçirmesi çok önemlidir. YÖK'ün almış olduğu kararlar ve önerileri doğrultusunda, yaklașık 80 bin öğrencisine uzaktan eğitim olanağı sağlayan Dokuz Eylül Üniversitesi yeterliliğini ve yetkinliğini bu noktada kanıtlamıştır. Sadece eğitimde değil hayatın bir çok alanında dijitalleşme ile birlikte online sistemlerin aktif olarak hayata geçmesiyle yeni bir dönem başlamış ve bu dönüşüm 21. yüzyılın en önemli gelişmelerinden biri olarak hayatımıza girmiştir.

Dijital sağlık, yıllar içerisinde önemi ortaya çıkan stratejik bir sağlık önceliği olarak görülmektedir. COVID-19 salgını öncesinde bile, sağlık sistemlerini ve hizmetlerini daha etkili hale getirmek için dijital sağlık teknolojilerinin kullanımı yaygın olarak kabul görmekteydi. Dijital sağlı̆̆ın oynayabileceği rol, COVID-19 salgını sırasında tekrar gündeme gelmiştir (www.euro.who.int, 2020). Sağlık Bakanlığl, sağlık hizmetleri sunmanın önemli dijital yollarından biri olan "izleme ve önleme için mobil sağlık uygulamaları" kullanımını hayata geçirerek "Hayat Eve Sığar" (HES) uygulamasını vatandaşların hizmetine sunmuştur.

HES uygulaması, işyerleri, restoranlar, ulaşım araçları, taksiler, nikah/düğün gibi toplu etkinlikler, kurum ziyaretleri gibi tüm sosyal alanlarda vatandaşlara güvenli sosyal hayat sunmak için geliştirilmiştir. HES'in içinde yer alan "Güvenli Alan" ve "HES Kodu Sorgulama ve Okutma" uygulaması ile vatandaşların riskli olup olmadığının, riskli kişilerle temas edip etmediğinin gözlemlenmesi, bulunduğu mekanların takibi ve güvenliği sağlanmaktadır. Uygulama ile tüm sosyal alanlar için riski en aza indirmek amaçlanmaktadır (web.archive.org, hayatevesigar.saglik.gov.tr, 2020)

Tüm dünya da olduğu Türkiye'de de Covid-19 pandemisi ile birlikte bir sosyal izolasyon süreci başlamış ve bu süreçte şirketler dijital yetkinlikleri ölçüsünde belirli tedbirler almışlardır. Pandemi dönemi öncesinde esnek çalışma modelleri uygulayan ve bu konuda teknik alt yapılarını kurmuş olan işyerleri bu sürece daha hazırlıklı girmişlerdir. 22 Mart 2020 tarihinde kamuda da esnek çalışmaya geçilmiş ve dolayısıyla bu süreç kamuda ve özel sektörde mekandan bağımsız yeni bir yaşam ve çalışma sisteminin hızla hayatımıza girmesine sebep olmuştur. 1 Haziran 2020 tarihinde normal hayata geçiş süreci başlamış ve kamuda esnek çalışma uygulaması sonlandırılmıştır. Fakat normalleşme süreci ile birlikte salgınının ülkemizde yayılımının en aza indirilmesi amacıyla, salgınla mücadeleyi ve salgının etkilerinin azaltılmasına yönelik faaliyetleri zafiyete uğratmama ve kamu hizmetlerini aksatmama şartıyla, 26 Ağustos 2020'de Cumhurbaşkanlığının yayınladığı 31225 sayılı ve "Covid-19 kapsamında kamu çalışanlarına yönelik tedbirler" konulu genelge ile tekrar yürürlüğe girmiştir (Resmi Gazete, 2020). Her ne kadar esnek, uzaktan ve dönüșümlü çalışma modeli, Covid-19 pandemisinin doğurduğu bir zorunlulukla tüm özel ve kamu sektöründe uygulanan bir sistem olsa da pandemi sonrasında da iş hayatında daha sıklıkla karşımıza çıkacak bir çalışma modeli olacaktır. $\mathrm{Bu}$ sebeple tüm sektörler teknoloji alt yapılarına ve iletişim araçlarına yapacakları yatırımları hızlandırmalıdır.

Pandemi ile birlikte işsizlik oranları artmış, turizm, ulaştırma ve hizmet sektörleri bu süreçten en çok etkilenen sektörler arasında yer almıştır. $\mathrm{Bu}$ süreçte üretim, ihracat ve istihdamın devamlılı̆̆ Ekonomik İstikrar Kalkanı paketi ile desteklenmiştir. Pandemi sürecinde bugüne kadar atılan adımların toplam tutarı 260 Milyar TL'ye ulaşmıştır. 


\section{N. HOTAR, R.E. OMAY, S. BAYRAK, Z. KURUÜZÜM, B. ÜNAL}

Haziran-Ağustos aylarını kapsayan iș gücü istatistikleri dikkate alındığında, işsizlik oranları 0.5 puanlık azalma ile \%13.4 seviyesinde gerçekleşmiştir. İstihdam edilenlerin \%54.9'u hizmet sektöründe yer almaktadır ve bu nedenle özellikle hizmet sektörüne yönelik istihdam politikaları geliştirilmelidir.

\section{REFERANSLAR}

https://ailevecalisma.gov.tr/eyhgm/yayinkaynak/ (2020)

https://www.aa.com.tr/tr/koronavirus/cumh urbaskani-erdogan-ekonomik-istikrar-kalkanipaketini-acikladi/1770929 (2020a)

https://www.aa.com.tr/tr/ekonomi/bakanalbayraktan-ekonomik-istikrar-kalkani-paketidegerlendirmesi/1850347 (2020b)

https://www.bbc.com/turkce/haberlerturkiye-51828267 (2020) "Koronavirüs (Covid-19): Sağlık Bakanı Koca, Türkiye'deki ilk virüs vakasını açıkladı"

https://www.hmb.gov.tr/haberler/basinaciklamasi (2020)

https://tr.euronews.com/2020/03/17/sagl-kbakan-koca-koronavirusle-mucadelemizdebugun-ilk-kez-bir-hastam-kaybettim (2020) "Türkiye'de koronavirüs nedeniyle ilk can kaybı; toplam vaka sayısı 98'e ulaştı"

https://ms.hmb.gov.tr/uploads/2020/09/YEN \%C4\%B0-EKONOM\%C4\%B0-PROGRAMIK\%C4\%B0TAP\%C3\%87IK.pdf (2020) "Yeni Ekonomik Programı"

https://www.sabah.com.tr/galeri/ekonomi/h azine-ve-maliye-bakanligi-yayinladi-isteekonomik-istikrar-kalkani-paketi-ve-digertedbirler (2020) "Ekonomik İstikrar Paketi ve Diğer Tedbirler"

Hotar N., Omay R.E., Bayrak S., Kuruüzüm Z., Ünal B. "Pandeminin Toplumsal Yansımaları, İzmir İktisat Dergisi, Cilt:35, Sayı:2, Sf. 221-220, 2020.

https://dergipark.org.tr/en/download/article -file/1176465 https://www.icisleri.gov.tr/sehir-giriscikistebirleri-ve-yas-sinirlamasi (2020a) "Şehir Giriş/Çıkış Tedbirleri ve Yaş Sınırlaması”

https://www.icisleri.gov.tr/81-ilesehirlerarasi-otobuslerde-hes-koduzorunlulugu-genelgesi (2020b)

https://www.icisleri.gov.tr/hes-uygulamasihayata-gecirildi (2020c)

http://www.meb.gov.tr/uzaktan-egitim-30nisana-kadar-devam-edecek/haber/20585/tr (2020a) “Uzaktan Eğitim 30 Nisan'a kadar devam edecek"

https://www.meb.gov.tr/bakan-selcukkoronaviruse-karsi-egitim-alaninda-alinantedbirleri-acikladi/haber/20497/tr (2020b) "Bakan Selçuk, Koronavirüs'e Karşı Eğitim Alanında Alınan Tedbirleri Açıkladı"

Resmi Gazete "Covid 19 Kapsaminda Kamu Çalışanlarına Yönelik Tedbirler" https://www.resmigazete.gov.tr/eskiler/2020 /08/20200826-5.pdf

https://dosyamerkez.saglik.gov.tr/Eklenti/39 024,haber-bulteni-2019pdf.pdf?0 (2020) "Sağlık İstatistikleri Yıllığı 2019 Haber Bülteni"

https://web.archive.org/web/202009161834 43/https://hayatevesigar.saglik.gov.tr/HES.pd f (2020) "Hayat Eve Sığar: Güvenli Alan-HES Kodu-İhbar"

https://hayatevesigar.saglik.gov.tr/HES.pdf

https://hasta.saglik.gov.tr/Eklenti/36907/0/p andemi-hastaneleripdf.pdf (2020) "Pandemi Hastaneleri" 
Şeker A.U., “Avrupalıların \%5,2'si Evden Çalışıyor"

https://www.aa.com.tr/tr/dunya/avrupalilari n-yuzde-5-2si-evden-calisiyor/1726142 (2020)

http://www.tuba.gov.tr/files/images/2020/k ovidraporu/T\%C3\%9CBA\%20Covid19\%20Raporu\%206.\%20G\%C3\%BCncelleme. pdf (2020) "Covid 19 Küresel Salgın Değerlendirme Raporu 6. Güncelleme"

https://biruni.tuik.gov.tr/bolgeselistatistik/ta bloOlustur.do?d-4326216-p=1\&d-4326216$\mathrm{s}=1 \& \mathrm{~d}-4326216-\mathrm{o}=2 \#$ (2020) "TÜIK Bölgesel İstatistikleri"

https://tuikweb.tuik.gov.tr/PreHaberBultenle ri.do?id=33791 (2020) "İşgücü İstatistikleri"

https://www.deik.org.tr/basin-aciklamalarihazine-ve-maliye-bakani-berat-albayrak-deiktalks-programinda-is-dunyasinin-sorulariniyanitladi (2020)

https://www.uab.gov.tr/basinaciklamalari/basin-aciklamasi-coronavirushakkinda (2020a) "Basın Açılaması: Koronavirüs Hakkında"

https://www.uab.gov.tr/basinaciklamalari/ucus-yasagi-olan-ulke-sayisi-68e-yukseldi (2020b) "Uçuş Yasağı Olan Ülke Sayısı 68'e yükseldi”

Yener D., Karaaslan D.S. "Sağlık Bakanı Koca: Yeni Dönem Kontrollü Sosyal Hayattır" https://www.aa.com.tr/tr/koronavirus/saglik -bakani-koca-yeni-donem-kontrollu-sosyalhayattir/1831309 (2020)
Yener, D. “Türkiye'nin Koronavirüsle Mücadele Politikasına Bilim Kurulu Yön Veriyor" https://www.aa.com.tr/tr/koronavirus/turkiy enin-koronavirusle-mucadele-politikasinabilim-kurulu-yon-veriyor/1777215 (2020)

https://covid19.yok.gov.tr/Documents/alinan -kararlar/02-coronavirus-bilgilendirme-notu1.pdf (2020) "Koronavirüs (Covid19) Bilgilendirme Notu:1"

Zengin, T. "Covid-19 Salgının İşgücü Piyasalarına Etkileri" https://kriterdergi.com/yazar/tarkanzengin/covid-19-salgininin-is-gucupiyasalarina-etkileri (2020)

https://www.who.int/dg/speeches/detail/wh o-director-general-s-opening-remarks-at-themedia-briefing-on-covid-19---11-march-2020 (2020a) "WHO Director-General's opening remarks at the media briefing on COVID-19 - 11 March 2020"

https://apps.who.int/iris/bitstream/handle/1 0665/335803/WHO-EURO-2020-116840914-55408-eng.pdf (2020) "Turkeys Response to Covid-19: First Impression",

https://www.euro.who.int/en/healthtopics/Health-systems/digitalhealth/news/news/2020/9/digital-healthtransforming-and-extending-the-delivery-ofhealth-services "Digital health: transforming and extending the delivery of health services" 